\title{
MEASUREMENT OF MAINTENANCE EXCELLENCE
}

\author{
Dušan Djurović, Miodrag Bulatovic, Mirko Soković, Antun Stoić
}

Original scientific paper

It is necessary for maintenance to have qualified and trained staff, capable of using modern equipment for maintenance, defect inspection and maintenance work, able of applying modern requirements of organization and management. Therefore, it is necessary to redesign the maintenance processes in a more extensive way than the classical, which is based on the terotechnological concept. Maintenance organization should be achieved at the same modern principles as the business excellence system of a company as a whole. This also includes a business philosophy that consists of the process approach to the design and operations of a company, an integrated management system based on the application of certain standards (quality, environment, safety at work, etc.) and elements of business excellence of a company. Maintenance excellence is a framework for a challenging and critical review of the integrity and productivity of any business process or project. Through maintenance excellence, any company seeks to provide a high quality process that supports continuous improvement focusing on various areas such as strategy, employees, information, work and other business aspects of maintenance.

Keywords: maintenance excellence; maintenance excellence index; models

Mjerenje izvrsnosti održavanja

Izvorni znanstveni članak U održavanju je potrebno imati kvalificirane i obučene zaposlenike kako za uporabu suvremene opreme za održavanje, za defektažu i izvođenje radova održavanja tako i za primjenu suvremenih zahtijeva organizacije i menadžmenta. Zbog toga je potrebno redizajnirati procese održavanja na širi način od "klasičnog", koje se bazira na terotehnološkom konceptu. Uređenje održavanja treba se ostvarivati na istim suvremenim principima na kojima se zasniva postizanje poslovne izvrsnosti sustava u cjelini. To ujedno uključuje i poslovnu filozofiju koju čine procesni pristup projektiranja i rada, integrirani sustav menadžmenta baziran na primjeni određenih standarda (kvaliteta, životna sredina, sigurnost na radu i dr.) i elementima poslovne izvrsnosti. Izvrsnost održavanja predstavlja okvir za izazovan kritički osvrt na cjelovitost i produktivnost svakog poslovnog procesa ili projekta. Kroz izvrsnost održavanja, organizacija nastoji osigurati visoku kvalitetu procesa koji podržava kontinuirani napredak u funkciji održavanja i usmjerava se na različita područja kao što su strategije, zaposleni, informacije, rad i ostali poslovni aspekti održavanja.

Ključne riječi: izvrsnost održavanja; indeks izvrsnosti održavanja; modeli

\section{Introduction - Models of maintenance excellence}

Maintenance is defined as the combination of all the technical and administrative actions, including supervision, intended to retain an item, or restore it to a state in which it can perform a required function (IEC, 2006) [1]. Maintenance is a key function in sustaining long-term profitability for an organization [2].

Measurement of maintenance performance is crucial for analysing the effectiveness of maintenance decisions, because maintenance performance cannot be managed, if it cannot be measured. From this reason some authors (Parida et al., 2005) [3] proposed a conceptual model of multi criteria maintenance performance measurement (MPM), based on maintenance performance indicators (MPIs), which are used for measurement of maintenance impact on the process performance. The two key issues are [4]:

- How to measure MPIs?

- How to select the right MPIs for measuring MPM?

Business excellence is synonymous with business success that includes all elements of the excellence of a company: production excellence, maintenance excellence, excellence in logistics and other elements.

Maintenance excellence is a framework for a challenging critical review of the integrity and productivity of any business process or project. Through maintenance excellence companies seek to provide a high quality process that supports continuous improvement and focuses on various areas such as strategy, employees, information, work, and other business aspects of maintenance $[5,6]$.
Criteria of maintenance excellence [5] are the guidelines for world maintenance practices. Using these criteria, a company will be able to assess its own options of maintenance through self-assessment.

Several models of maintenance excellence are associated with awards in the areas of quality and present a useful framework for quality and effectiveness improvement:

- The Australian model of maintenance excellence (2007) seeks to provide a high quality process and supports continuous improvement in order to maintain, with special emphasis on employment, practice and business.

- The North American Excellence Maintenance model (2007) through its annual program recognizes organizations that make a difference in the performance of the maintenance process to enable excellence.

- $\quad$ Since the late 1990 s the TPM excellence model has been ingrained as a continuous improvement methodology in a wide range of industries.

- The Japanese model of excellence (Shingo, 2007) is that total system model that includes all aspects of maintenance.

Regardless of the level, in every organization there is a need for proper development in maintenance, as well as for achieving maintenance excellence as a condition for adequate profitability $[7,8]$.

It is not possible to give a standard recipe for achieving maintenance excellence, given the complexity of maintaining position in various organizations, but it is possible to explain some of the common aspects of different types of industries. 
Maintaining excellence, a very complex set of activities, and performance derived from that, is comprised of the following elements [6]:

- maintenance management,

- maintenance and organizational culture,

- organization and administration in maintenance,

- maintenance strategies,

- engineering support,

- development of craft skills,

- planning in maintenance,

- plant, equipment and tools,

- maintenance preparation,

- $\quad$ preventive and predictive maintenance,

- maintenance technologies,

- maintenance techniques,

- effectiveness of maintained equipment,

- storage in maintenance process,

- control in maintenance,

- security and compliance,

- cost management,

- measurable characteristics of maintenance elements performance.

The definition of maintenance objectives can be viewed as a $\max / \mathrm{min}$ principle - maximizing the output of maintenance that meets the technical accuracy of the equipment, minimizing inputs for maintenance in terms of the number of employees, financial resources and costs in general.

The most important thing is that all input factors interact with each other, considering that relatively small changes in any of the input factors can significantly affect the output or the working ability of the equipment.

There are many concepts of maintenance and improvement strategies such as: TPM - total productive maintenance, RCM - reliability centred maintenance, RBI - risk based inspection, LCC - life cycle costing, CMMS computerized maintenance management software, maintenance management, spare parts management etc.

Problems arise when organizations use more than one concept simultaneously and start a new project in the middle of unfinished work, leading to the dissatisfaction of all participants in the project. The situation becomes even more complicated if the organization changed targets to improve maintenance from using increasing equipment effectiveness (reliability and availability) to reduce costs and vice versa.
Summarizing all these aspects, it can be concluded that organizations that have not established adequate grounds for maintenance have problems to reach excellence in the management of maintenance.

The road to excellence in manufacturing should begin with the desire to achieve world-class maintenance or maintenance excellence. There are five basic requirements, according to $[5,6]$ :

- Maintenance "always".

- Determining where you are? Profit is as an indicator of maintenance excellence.

- Developing of Computerized Maintenance Management CMMS/EAM System Maintenance Management.

- Maintenance work directed to company profit Revenue optimisation.

- Maintenance excellence index.

Particularly interesting is the index of maintenance excellence (Total Maintenance Excellence Index - TMEI) [8] which is an essential component for defining the performance of maintenance and the data to inform the customer of maintenance services.

\section{Preliminary research of maintenance excellence}

The research of maintenance excellence in our case was carried out in a real environment of a successful construction organization involved in civil engineering (construction of roads and road infrastructure). The organization owns modern machinery and transport equipment and employs around 200 workers of the needed professional profile. It is organized in a contemporary way, on the principles of an integrated management system and is certified according to the standards of ISO 9001, ISO 14001 and OHSAS.

The motives for a wider research of maintenance excellence were the results and the experience acquired with the self-assessment of the organization in the area of business excellence according to the EFQM model.

\subsection{Results of self-assessment based on EFQM mode}

Previous studies of business excellence based on the criteria of the EFQM model of evaluation were carried out in 2013. The preliminary results of the selfassessment are shown in Tab. 1 [9].

Table 1 Results of self-assessment according to EFQM model

\begin{tabular}{|l|c|c|l|}
\hline \multicolumn{1}{|c|}{ Criterion } & EFQM Excellence Model & RatingcompaniesonEFQM Model & \multicolumn{1}{c|}{ Comments } \\
\hline Enablers & 500 & 320 & Need Improvement \\
\hline Leadership & 100 & 80 & Satisfies \\
\hline People & 90 & 60 & Need Improvement \\
\hline Strategy & 80 & 50 & Need Improvement \\
\hline Partnership \& Resources & 90 & 50 & Need significant improvement \\
\hline Processes & 140 & 80 & Need significant improvement \\
\hline Results & 500 & 370 & Seed Improvement \\
\hline People Results & 90 & 70 & Satisfies \\
\hline Customer Results & 200 & 150 & Satisfies \\
\hline Society Results & 60 & 50 & Satisfies \\
\hline Business Results & 150 & 100 & Need significant improvement \\
\hline Total & 1000 & 690 & Level of excellence: Emphasized continuous improvement \\
\hline
\end{tabular}

The result, the distribution of points, is a result of a combination of the Delphi and Brainstorming method, the analysis of criteria by those familiar with the state in the organization - based of years of work and experience in 
the work organization (top management) - as well as experts in this field, those familiar with the organization. The assessment was informal.

The results of the self-assessment indicate that the company emphasizes continuous improvement, that there exist good results and trends of improvement, therefore the company is successful, with a trend of further improvement.

\subsection{Results of research of the level of maintenance successfulness}

Previous research of the level of successful maintenance in the observed organization was carried out simultaneously with the process of self-assessment according to the EFQM model by using the approved model of the Dublin Institute of Technology [6]:

- management (organization),

- employees - qualification structure,

- planning in maintenance,

- maintenance process (maintenance techniques and technologies),

- equipment reliability,

- business characteristics (costs, economy).

The preliminary research results of the level of maintenance successfulness are given in Tab. 2 and the graphical chart in Fig. 1 [10].

The research results show a satisfactory reliability of equipment, even though there are some deficiencies in the qualification structure and organization which increases maintenance costs [11].
Table 2 Summary table with research results of level of successful

\begin{tabular}{|c|l|c|c|c|}
\multicolumn{5}{|c}{ maintenance [6] } \\
\hline & \multicolumn{1}{|c|}{ Areas of research } & $\begin{array}{c}\text { The max } \\
\text { value }\end{array}$ & $\begin{array}{c}\text { Middle } \\
\text { realized } \\
\text { value }\end{array}$ & Rank \\
\hline 1 & Management (Organization) & 5 & 3,8 & IV \\
\hline 2 & $\begin{array}{l}\text { Employees - Qualification } \\
\text { structure }\end{array}$ & 5 & 3 & VI \\
\hline 3 & Planning in maintenance & 5 & 4 & III \\
\hline 4 & $\begin{array}{l}\text { Maintenance process } \\
\text { (Maintenance techniques and } \\
\text { technologies) }\end{array}$ & 5 & 4,4 & I - II \\
\hline 5 & Equipment reliability & 5 & 4,4 & I - II \\
\hline 6 & $\begin{array}{l}\text { Business characteristics } \\
\text { (Costs, Economy) }\end{array}$ & 5 & 3,25 & V \\
\hline & $\begin{array}{l}\text { Achieved level of success of } \\
\text { maintenance }\end{array}$ & & $\begin{array}{c}3,871 \\
(77,42 \%)\end{array}$ & \\
\hline
\end{tabular}

\section{Model of maintenance excellence index}

The index of maintenance excellence is a complex value that represents a progressive approach to managing maintenance activities on the basis of metric elements. Tab. 3 shows the basis of the model of maintenance excellence index, which is based on the model of excellence established at the Dublin Institute of Technology [6].

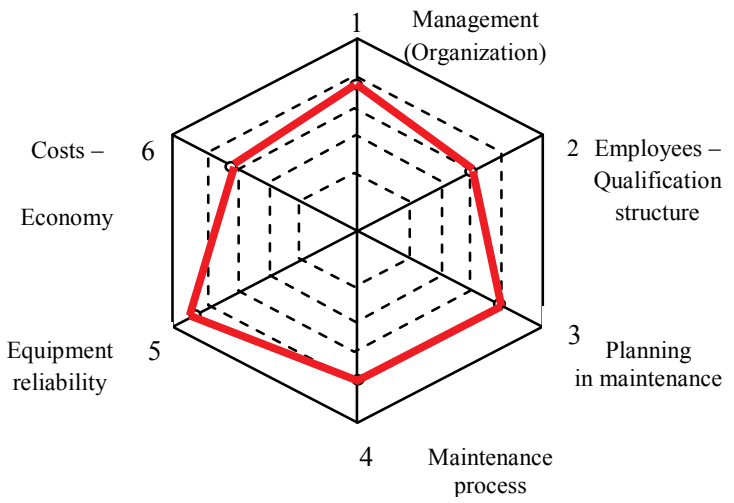

Figure 1 Graphical representation of research results of maintenance successfulness [10]

Table 3 The basis of the model of maintenance excellence index

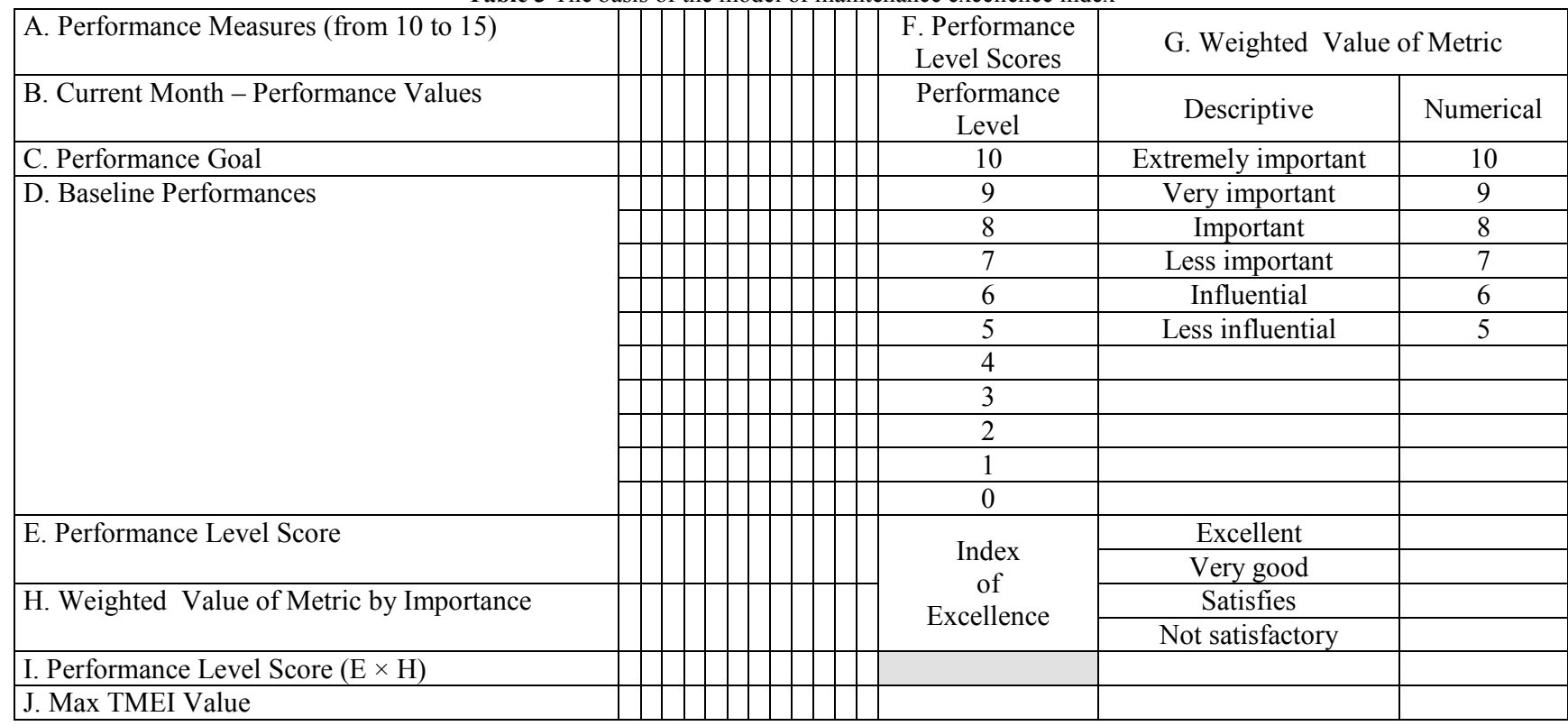


The model consists of 10 elements $(A \div \mathrm{J})$ for calculating the index value:

A- Performance measures - include 10 to 15 key performance indicators (in percentage of achieving)

B- Current month performance - data in the current month or in the researched period

C- Performance goal - planned, recommended by literature, obtained by benchmarking

D- Baseline performance - weighted value measures in relation to target value of measuring characteristics (pondered in the negative sense in relation to target values), determined by the organization measuring the excellence index

E- Performance level score

F- Performance level and index of excellence

G- Weighted value of metric - predetermined

$\mathrm{H}$ - Weighted value of metric by importance - expert assessment

I- Performance level score $(E) x$ weight $(\mathrm{H})$ - sum of the products $(\mathrm{E}) \times(\mathrm{H})$ gives the value of the maintenance excellence index

J- The maximum value of the target performance (Hx10) depends on the ponder assigned to the characteristic $(\mathrm{H})$ and maximum level of pondered performances (10), and its result is the TARGET index of excellence.
Based on the results of the mentioned studies (Chapter 2) the organization decided to conduct further research by using the model of maintenance excellence index.

The applied model of excellence index [8] included 12 significant metric elements for the maintenance process (A), whose values (B) were determined during the research and are given in \% in relation to the required ones - planned target values of measurement characteristics $(\mathrm{C})$ :

Measurement characteristics (A1 - A12) B (\% of C)

1. Actual main. costs per unit of prod. $\quad 130 \%$

2. Labour cost within $5 \%$ of cost estimate $90 \%$

3. Overall main. costs compared to budget $94 \%$

4. Overall realized planned main. activities $90 \%$

5. Overall compliance of main. plan $\quad 94 \%$

6. Planned work in relation to unplanned $68 \%$

7. Rework (repetitions of work) $75 \%$

8. Work orders with reliable planned time $50 \%$

9. Critical asset availability $\quad 90 \%$

10. Utilization time $75 \%$

11. Working time availability $\quad 90 \%$

12. Stock availability - spare parts $\quad 90 \%$

After entering the numerical values of metric elements (B) the model shown in Tab. 4 was acquired. It relates to the studied organization.

Table 4 The model of maintenance excellence index relates to the studied organization Maintenance Excellence Index Example (Research in construction company)

\begin{tabular}{|c|c|c|c|c|c|c|c|c|c|c|c|c|c|c|c|}
\hline 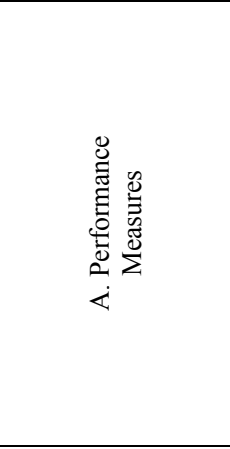 & 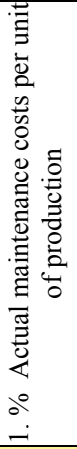 & 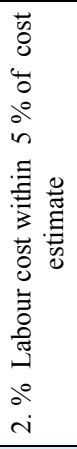 & 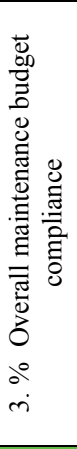 & 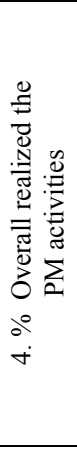 & 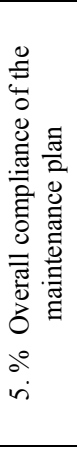 & 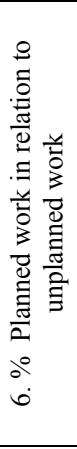 & 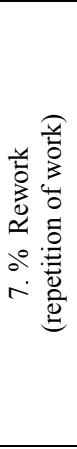 & 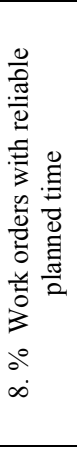 & 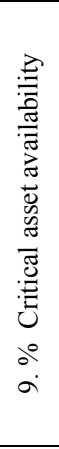 & 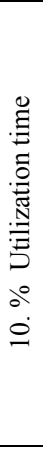 & 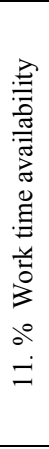 & 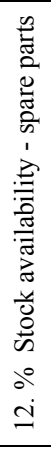 & 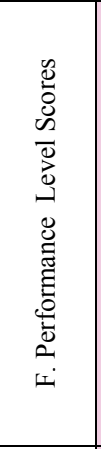 & 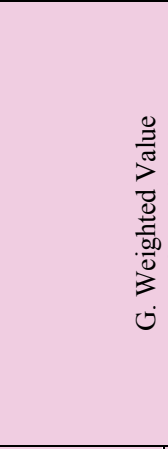 & \\
\hline B. Current Month & 1,30 & 90 & 94 & 90 & 94 & 68 & 75 & 50 & 90 & 75 & 90 & 90 & $\begin{array}{l}\text { Perf. } \\
\text { Level }\end{array}$ & Descriptive & Numerical \\
\hline $\begin{array}{l}\text { C. Performance } \\
\text { Goal }\end{array}$ & 100 & 95 & 98 & 95 & 100 & 80 & 85 & 60 & 95 & 80 & 98 & 95 & 10 & $\begin{array}{l}\text { Extremely } \\
\text { important }\end{array}$ & 10 \\
\hline \multirow{10}{*}{$\begin{array}{l}\text { D. Baseline } \\
\text { Performance }\end{array}$} & 1,05 & 94 & 96 & 94 & 98 & 78 & 83 & 58 & 94 & 78 & 98 & 94 & 9 & $\begin{array}{c}\text { Very } \\
\text { important }\end{array}$ & 9 \\
\hline & 1,10 & 93 & 94 & 93 & 96 & 76 & 81 & 56 & 93 & 76 & 96 & 92 & 8 & Important & 8 \\
\hline & 1,15 & 92 & 92 & 92 & 94 & 74 & 79 & 54 & 92 & 74 & 94 & 90 & 7 & $\begin{array}{c}\text { Less } \\
\text { important }\end{array}$ & 7 \\
\hline & 1,20 & 91 & 90 & 91 & 92 & 72 & 77 & 52 & 91 & 72 & 92 & 88 & 6 & Influential & 6 \\
\hline & 1,25 & 90 & 88 & 90 & 90 & 70 & 75 & 50 & 90 & 70 & 90 & 86 & 5 & $\begin{array}{c}\text { Less } \\
\text { influential }\end{array}$ & 5 \\
\hline & 1,30 & 89 & 86 & 89 & 88 & 68 & 73 & 48 & 89 & 68 & 88 & 84 & 4 & & \\
\hline & 1,35 & 88 & 84 & 88 & 86 & 66 & 71 & 46 & 88 & 66 & 86 & 82 & 3 & & \\
\hline & 1,40 & 87 & 82 & 87 & 84 & 64 & 70 & 44 & 87 & 64 & 84 & 80 & 2 & & \\
\hline & 1,45 & 86 & 80 & 86 & 82 & 62 & 69 & 42 & 86 & 62 & 82 & 78 & 1 & & \\
\hline & 1,50 & 85 & 78 & 85 & 80 & 60 & 67 & 40 & 85 & 60 & 80 & 76 & 0 & & \\
\hline E. Performance & 4 & 5 & 8 & 5 & 7 & 4 & 5 & 5 & 5 & 8 & 5 & 7 & \multirow{4}{*}{ 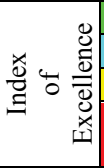 } & Excellent & $700 \div 870$ \\
\hline Level Score & 4 & 5 & $\gamma$ & 5 & 1 & 4 & 5 & 5 & 5 & $\gamma$ & 5 & 1 & & Very good & $500 \div 699$ \\
\hline H. Weighted & & & & & & & & & & & & & & Satisfies & $350 \div 499$ \\
\hline $\begin{array}{l}\text { Value of Metric } \\
\text { by Importance }\end{array}$ & 10 & 6 & 8 & 8 & 9 & 6 & 6 & 7 & 10 & 9 & 8 & 9 & & $\begin{array}{c}\text { Not } \\
\text { satisfactory }\end{array}$ & $<350$ \\
\hline $\begin{array}{l}\text { I. Performance } \\
\text { Level Score }(E) \times \\
\text { Weight }(H)\end{array}$ & 40 & 30 & 64 & 40 & 63 & 24 & 30 & 35 & 50 & 72 & 40 & 63 & 551 & Very good & \\
\hline $\begin{array}{l}\text { J. Max. MEI Value } \\
(\mathrm{H} \times 10)\end{array}$ & 100 & 60 & 80 & 80 & 90 & 60 & 60 & 70 & 100 & 90 & 80 & 90 & 870 & & \\
\hline
\end{tabular}




\subsection{Analysis of results}

The analysis of the level of individual performance (I) in Tab. 4 shows the level of reached target value for individual elements of excellence, based on which the following corrective activities are suggested:

- $\quad$ should reduce maintenance costs per unit of product A1,

- need to reduce labour costs - A2,

- should increase performance of planned activities A4,

- $\quad$ should increase amount of planned work in relation to unplanned - A6,

- should increase amount of repetitive work (prevention and lubrication) - A7

The following characteristics stand out as satisfactory:

- total costs compared with planned costs - A3,

- total compliance of maintenance plan - A5,

- $\quad$ orders with reliable scheduled time - A8,

- availability of material resources - A9,

- utilization time - A10,

- availability of working time - A11,

- availability of parts inventory - A12

From Tab. 4 it follows that the overall level of performance value or the maintenance excellence index in the studied organization is 551 , which is $57 \%$ of the maximum value of 960 . According to the scale of weights for significance $(G)$, the obtained index of excellence is "very good" [8].

Differences in the result of maintenance successfulness in relation to the determined maximum values - self-assessment $69 \%$, level of maintenance successfulness $77 \%$, and maintenance excellence index $57 \%$ - point to randomness of the data used in the research, which is a result of the methods used (Delphi and Brainstorming method).

\section{Conclusions}

In order to achieve a world-class level of maintenance excellence, it is necessary to redesign the processes of maintenance in a modern way instead of the "classic" one that is based on the terotechnological concept.

Maintenance organization should be realised with the same modern principles as the business excellence of a company as a whole. This includes a business philosophy that consists of the process approach to the design and operations of the organisation, an integrated management system based on the application of certain standards (quality, environment, safety at work, etc.) and elements of business excellence of a company.

The Maintenance Excellence Criteria - MEC are the guidelines for the introduction of world maintenance practices. Using these criteria, the organization will be able to assess its maintenance options through selfassessment.

The maintenance excellence index is an indicator of the maintenance level defined by a specific confirmation of success.
The present model for calculating the maintenance excellence index is based on the model used by the Dublin Institute of Technology and is very effective and flexible in terms of metric units - measuring characteristics of maintenance.

\section{Note}

The responsible translator for English language is Urška Letonja Grgeta, Videm, Slovenia.

\section{References}

[1] International Electrotechnical Commission. "International electrotechnical vocabulary", IEV 191-07-01, 2006 , available at: http://std.iec.ch/iev/iev.nsf.

[2] Al-Sultan, K. S.; Duffuaa, S. O. Maintenance control via mathematical programming. // Journal of Quality in Maintenance Engineering. 1, 3(1995), pp. 36-46. DOI: 10.1108/13552519510096341

[3] Parida, A. et al. Multi criteria maintenance performance measurement: A conceptual model. Proceedings of COMADEM 2005, September 2005, Cranfield, UK, pp. 349-356.

[4] Parida, A., Kumar, U. Maintenance performance measurement (MPM): Issues and challenges. // Journal of Quality in Maintenance Engineering. 12, 3(2006), pp. 239251. DOI: $10.1108 / 13552510610685084$

[5] Peters, R. W. "Pete". Maximizing Maintenance Operations for Profit Optimization: The Journey to Maintenance Excellence. The Maintenance Excellence Institute, Division of Ralph W. Peters and PEOPLE Inc. 6809 Foxfire Place, Suite 100, Raleigh, North Carolina, 2002, URL: http://www.plant-maintenance.com/articles/ JourneytoMaintenanceExcellence-Introduction.pdf

[6] Liggin, P. The Research and Implementation of Maintenance Excellence on Clean Utility Systems in the Pharmaceutical Industry. Masters Dissertation. Dublin, DIT, 2008.

[7] Okhovat, M. A. et al. Development of world class manufacturing framework by using six-sigma, total productive maintenance and lean. // Scientific Research and Essays. 7, 50(2012), pp. 4230-4241.

[8] The Reliability \& Maintenance Excellence Index: http://www.pride-in-maintenance.com/files/ introductionto-reliability-maintenance-excellence-index.pdf

[9] Djurović, D.; Bulatović, M. Održavanje kao uslov poslovne izvrsnosti u gradjevinarstvu, XV Nacionalni naučno stručni skup "Sistem kvaliteta uslov za uspešno poslovanje i konkurentnost", Kruševac, 2013.

[10] Djurović, D.; Bulatović, M. Izvrsnost održavanja, Konferencija održavanja i proizvodnog inženejeringa KODIP-2014, Budva, 2014

[11] Bulatović, M. Maintenance and effectiveness of technical systems, Monograph, Faculty of Mechanical Engineering, Podgorica, 2008. (Održavanje i efektivnost tehničkih sistema, Monografija, Mašinski fakultet, Podgorica, 2008). 


\section{Authors' addresses}

Dušan Djurović, PhD candidate

University of Montenegro, Faculty of Mechanical Engineering,

Cetinjski put bb, 81000 Podgorica, Montenegro

E-mail: dusan-dj@t-com.me

Miodrag Bulatović, Full Prof.

University of Montenegro, Faculty of Mechanical Engineering,

Cetinjski put bb, 81000 Podgorica, Montenegro

E-mail: bulatovm@ac.me

Mirko Soković, Full Prof.

Universityof Ljubljana, Faculty of Mechanical Engineering,

Aškerčeva c. 12, 1000 Ljubljana, Slovenia

E-mail: mirko.sokovic@fs.uni-lj.si

Antun Stoić, Full. Prof.

Mechanical Engineering Faculty in Slavonski Brod

J. J. Strossmayer University of Osijek

Trg Ivane Brlić Mažuranić 2

35000 Slavonski Brod, Croatia

E-mail: astoic@sfsb.hr 